\title{
The Roots of Terrorism in Imam Ali's Thoughts
}

\author{
Ali Adami ${ }^{1} \&$ Marzieh Mohammadi Nasab ${ }^{2}$ \\ ${ }^{1}$ School of Law and Political Science, Allameh Tabatabai University, Iran \\ ${ }^{2}$ International Relations, Allameh Tabatabai University, Iran \\ Correspondence: Ali Adami, School of Law and Political Science, Allameh Tabatabai University, Iran. E-mail: \\ shahrzad.researcher@gmail.com
}

Received: July 21, 2016 Accepted: August 26, 2016 Online Published: October 30, 2016

doi:10.5539/jpl.v9n9p84 URL: http://dx.doi.org/10.5539/jpl.v9n9p84

\begin{abstract}
In order to undermine Islamic discourse and to strengthen the Western discourse, terrorism-related issues have become popular among researchers and political analysts in recent decades especially after September 11th, 2001 in the United States to the extent that many people claim that Islam and Muslims are the epitome of terrorism and violence. Hence, this article aims to investigate the roots of terrorism based on strategic and operational policies of Imam Ali against the Kharijites, as the first terrorist group claiming Islam. The main question outlined here is based as follows: what are the intellectual and practical contexts of formation of terrorist groups? The main hypothesis outlined here is as follows: Considering the strategic and operational policies of Imam Ali against the Kharijites, it is claimed that intellectual and practical contexts and roots of terrorist groups are based on targeted injection of interpretation and a deviated definition of Islamic beliefs and values.
\end{abstract}

Keywords: crisis of beliefs, terrorism, violence, smart power

\section{Introduction}

When globalization was recognized as an accepted phenomenon in the 1990s, some scientists claimed that it is the time to realize the technically functional failure of the nation-state and norms in dealing with distributive justice and interdependence of globalization. Therefore, theory construction was felt concerning the global democratic governance. These calls, however, would assume that political theory can globally and internationally be taken into account without the prefix. In any case, the idea of global democratic governance is less regarded than the discourse of domination known asworld public opinion (Chong, 2012: 143). Public opinion may move around a dramatic character; however, perceptions and attitudes are sustainable characteristics of any community and this requires a continuous and comprehensive effort to change to optimal and reliable objective which would remain sustainable (Parmr and Cox, 2012: 261). All studies conducted in the field of the United Nations public opinion during some crises such asBalkan crisis, terrorism, or Arab-Israeli war indicate that pro-UN consider "world public opinion" only a moral justification (Chong, 2012: 124).

Professor Richard Bulliet, Columbia University believes that Americans have easily accepted that violent acts by some Muslims represent an ossified and terrorist culture that they cannot be negotiated with. Bullit does not hide his fear of the fact that the U.S. might face new kinds of anti-Semitism which is not based on Jewish race but Islam. He states that we have decided to reach a point where people easily accept that there is a terrorist threat from Muslim religious extremists (Girgis, 2003: 92).

Terrorism, as a political tool, is not a new phenomenon. In the past especially during the Roman Empire, it used to be applied. Political assassinations have often been a more general form of political terrorism (Moazami and Namamian, 2014: 61). Political terrorism is a method of warfare (Chaliand and Blin,2007:12). Terrorism is basically a tactic and a means to achieve political goals through terror and fear (Scheinin, 2008:10). From one aspect, modern terrorism differs from that of the past in which the victims are often innocent civilians either randomly selected or present in terrorist circumstances. In other words, blindterror victims outweigh the assassination of prominent figures (Dardarian and others, 2003: 41). Psychologically, violence against innocent people is far more horrifying than political violence in which political figures are targeted. Triggering angry dissidents assassinate hated political officials and kidnap foreign diplomats and consultants support oppressive regimes are far easier .Cruel slaughter of innocent women and children in buses, shops and airports, would require stronger mental machinations that aggravate the moral promiscuity (Rayesh, 2002: 268). Concerning the 
response to terrorist attacks, some governments especially Israel, the United States and South Africa, in the past, believed that they are allowed to turn to force to target terrorist databases in the host countries in self-defense. The justified this by claiming the fact that such countries are inciting terrorism by sheltering the terrorist organizations or at least tolerating them. As a result, they are "partner in crime". They are responsible for this so-called indirect armed aggression (Dardarian and others, 2003: 361).A definite purpose in the anti-terrorism policies can be limiting the severe conflicts around the world(Compos and Gassebner, 2009:25).Uselessness and ineffectiveness of war on terrorism might be apparent in Iraq in in large-scale armed conflict (Plous and Zimbardo, 2004:10). In 2014, most attention to global terrorism in Islamic countries, Iraq, and the eastern bank of the Mediterranean includes the unprecedented conflicts in Iraq and Syria, continued increase of cross-border terrorist fighters around the world to join the Islamic countries in Iraq and the eastern bank of the Mediterranean, and rising severely criminal extremists in the West (Country reports on terrorism 2014,2015:7). In 2014 and 2015,the number of terrorist attacks increased in Afghanistan compared to 2013. As a result of these attacks, 5411 people were killed and 5108 others were wounded (Pawlak, 2015:6). Al Qaeda and its supporters around the world continue to pose a serious threat against America and its allies and interests. As long as the international community undermined the leader of al-Qaeda, the terrorist threats have increased (Country reports on terrorism 2013, 2014:6). Professor Tomuschat reviewed the legal findings of scholars of international law within the framework of the French Society of International Law conducted in 2004. He concluded that, by summarizing the findings of authors, it is claimed that they all have reached a consensus concerning the fact that there is no need to abandon the accepted standards of human rights and, more importantly Covenant on Civil and Political Rights, on the one hand, and the European Convention on Human Rights, on the one hand to fight terrorism. Therefore, not only human rights have no conflict with the fight against terrorism but also they ensure the effectiveness of such fight (Abdullahi, 2009: 127). Are human rights standards respected in reality while fighting with terrorism? Is terrorism, as the most highlighted dilemma of contemporary era, a challenge or opportunity for the main actors in the international system. In the centrality of the Middle East and Islam in the accumulation of terrorism, religious and regional variables are dependent or independent variables? Now, we will review the Imam Ali's point of view concerning the terrorism.

\section{Intelligent Management in Counterinsurgency Strategy}

Imam Ali's intelligent management is based on rigid moral principles and flexibility in tolerance with people. Imam Ali's rigid moral principles consist of management elements such as justice, equality, honesty, etc. Meanwhile, his flexibility in tolerance with people includes sacrifice, forgiveness, mercy, etc. reflected in his political behavior. Imam Ali`s intelligent power management direct soft and hard power elements toward social justice so that the nature of hard and soft power reflect universal common values and humanitarian policy. Such policies are valuable concerning the principles of good faith, non-use of force, non-aggression, self-determination right, self-defense, and the prohibition of war crimes. Imam Ali`s strategic management against rebels is reflected in the following verse:

"Whoever kills a person-unless it is for murder or corruption on earth-it is as if he killed the whole of mankind" (Al-Mai'dah: 32).

The agenda of Imam Ali's intelligent power management is the social justice against both supporters and enemies. Oppositional leadership in the formulation of Imam Ali`s management is not the reason for the denial of justice. Power's prestige and legitimacy are the ability to promote the value functions. Prescribing democracy does not match with force and dictatorship; defend human rights, human slaughter, and the spread of freedom with security repression. Nye states that:

2003 Iraq war provided an interesting example of the two power's confrontation. Some of the war incentives were deterrent effect on hard power. Donald Rumsfeld (Secretary of Defense of America) stated in one of his reports: once I began working on this position, I believed that people consider the U.S. a paper tiger around the world: A weak monster that does not have the ability to strike. Therefore, I decided to restore this loss. In addition to victory in this war, Iraq war would block the future support of other governments to terrorists. They were the hard reasons to enter the war. Other incentives, however, depended on "soft power". Neoconservatives believed that US power can be used to send democracy to Iraq or change the Middle East policies. If is successfully done, was would automatically be legitimate. As William Kristol and Lawrence Kaplan stated there is no problem for a superior and dominant power to be in the service of higher principles and ideals (Nye, 2010: 72-73).

That the government and the dominant power are in the service of the true principles and high ideals is not a problem. The problem, however, begins when the true principles and high ideals are in the service of dominant 
power. America's political output functions not only are capable of adapting with the true principles and high ideals, but also form a separate range of profit-based principles and monopoly ideals. Framework of liberalism is not naturally valuable. The main function if soft power in western discourse through promotion of the values formed in imaging. Such images cover the value gap of objective facts. This determines the special work of priority regulation in management of west intelligent power. Nye states that:

At the strategic level, the counterinsurgency character gives great importance to trade-off between the military power necessary to clear an area, and damage to civilian force that their hearts and minds must be won. In some cases, trade-offs are inevitable .Pakistan drone strikes against al-Qaeda fighters, for instance, are one of the few tools that is available in North Pakistan. Such attacks, however, undermine America's soft power in the public eye of Pakistan (Nye, 2011: 335-336).

Nye's intelligent strategy believes inaggression and exploitation at the same time. However, he believes that appropriate direction of this topic toward civilian and military categories is inevitable. The cost of American democracy and human rights is killing the innocent and oppressed victims as a result of false legitimacy and credibility of a hegemonic power politics. Imam Ali`s intelligent management incounterinsurgency strategy is also based on social justice. Battle of Nahrawan is Imam Ali's best documented example of counterinsurgency management as follow:

After the unsatisfactory conclusion to the Battle of Siffin, Ali ibn Abi Talib returned with his army back to Kufa. Kharijites camped at a village named Harura. They began saying that all Muslims were equal and no one could rule over another, denouncing both Ali ibn Abi Talib and Mu'awiyah while proclaiming that their belief was in "La Hukma illa Lillah", meaning, "No Rulership except by Allah alone."Then Imam Ali himself went to the Kharijite encampment and tried to explain to them that they were misunderstanding the words "La Hukma illa Lillah", and that in accepting the Arbitration (peace talks) at Siffin, he had not gone against the teachings of the Quran.He pointed out that they themselves laid down their arms and forced him to call back Malik al-Ashtar, who was at the point of securing victory. He reminded them that they had pressed for the Arbitration and had forced him to appoint Abu Musa al-Ash'ari as his (and thus their) representative, after having rejected Ali's nominees, ibn Abbas and Malik al-Ashtar. He told them that he found their present behavior very strange, considering their involvement in the army revolt at Siffin. To this they admitted that they had sinned but now they had repented for it and he should do the same.Ali replied that he was a true believer and did not have to repent because he had not committed any sin; more discussion proved fruitless, and he dispersed the Kharijite representatives.

The Kharijites refused to accept the words of Ali and awaited the decision of Amr ibn al-'As and Abu Musa al-Ash'ari. When they learnt of the decision they decided to revolt, setting up their headquarters at Nahrawan, twelve miles from Baghdad. A group of sympathizers from Basra came to join the rebels. (Ibne Abi Al-Hadid, 1996, V. 1: 412-413, 1999, V. 2: 310-311)

Kharijites are the most important extremist group against Imam Ali. They used to spread rumors, were publicly insulting Imam Ali, interrupt the Imam Ali's congregational prayers, and disturbed Imam Ali's speeches .Kharijites expressed their hatred in any way and held secret and public series of meetings to cope with Imam Ali. Despite such insulting and sometimes threatening and dangerous practices, Imam Ali never took any violent and even legal reaction to arrest and deal with them. Imam Ali also used to pay their contribution from the national treasury, guided them, and called for rational discussion. Then, they left Kufa to surrounding areas and started killing people and unrest. Imam Ali sent them a message and advised them to stop such activities. Then, he himself went and talked to them. Some realized their false activities, however, the rest insisted on their beliefs. Battle of Nahrawan then occurred (Ali Khani, 2001: 53).

\section{Setting Priorities in the Counterinsurgency Strategy}

Kharijites who did not support Imam Ali from the first days began to threaten people to kill. Some of them went to Nahrawan coast.A man came out of the village in fear, they rushed to him and because he opposed their own opinions, they killed him. Then, they got his pregnant wife and killed him. Imam Ali chasedKharijites. As he approachedKharijites, they shot Imam Ali. The guards said: "Imam Ali, they are shooting us". Imam Ali told:" Wait for while". As they shoot for the third time, Imam Ali said: "Now, it is time to war, attack them.". (Ibne Abi Al-Hadid, V.1: 381-383, V.2: 269-271).

The first wave of terrorists and extremists in Islam was formed from the Kharijites. Imam Ali`s policy toward Kharijites is a symbol of defensive policy against terrorists. If Imam Ali's adherence to commitments to the enemy caused the formation of anti-Alawite group, America's failure to comply with the international obligations led to the the formation of anti-American extremists .If Alawite management project followed the negotiations 
with extremists in the atmosphere of freedom, American management project followed threatening the world with zero-sum game. Although national security strategy of Alawite took the persuasion policy toward extremists in its agenda, America's national security strategy and military policy against extremists set the agenda. Although smart power of Alawite fairly managed defensive policies against the extremists, US smart power managed unfairly aggressive policies against extremists. Although Alawite's management objective of confronting the extremists was balancing the rights in line with the social justice, America's management objective of confronting extremists is turning the balance of power in favor of American profit-driven and monopoly. Therefore, power elements in Alawite's smart management in converting to power behavior are the reflection of social justice and promotion of appealing; however, the power elements in America's smart management in converting to power behavior are reflecting social oppression and disgust. Nye states that:

That US response to terrorism has no conformity with its mentioned values damages American appeal. It was likely to predict that when International Human Rights Organization describes Guantanamo as "human rights scandal and disgrace" and Human Rights Watch accused the United States undermining its policies and position through duplicity and hypocrisy to accept values, such policies show pharisaic points of views for the public (Nye, 2010: 123-124).

The false front takes aggressive policies into account due to lack of reasoning and calls it preemptive defense in order to use the human rights to reach the profit-driven ladder and monopoly by its hard power and smart management power. The legitimacy is not won by the invasion and aggression on the rights of others even if cyber-wave frequencies promote this legitimacy worldwide. Nye states that:

Not only do players try to be effective in each other by soft power directly and indirectly, but also they compete to exclude each other of appeal and legitimacy. Therefore, they create a debilitating environment in public opinion in another country or the third parties (Nye, 2011: 163)

Considering Nye's point of view, players`competition to exclude each other from appeal and legitimacy can be generalized to other players. If one side of competition tries to accuse and discredit the legitimacy and attractiveness of rival, the other side tries to notify to eliminate the charge. Looking at the roots of political behavior from the inside-out perspective clarifies the realities. Legitimacy requires no proof or reason since it is a right to have. Falsehood tries to increase the legitimacy frequency in order to gain it. Falsehood also tries to hide in shadow of delegitimizing others. Geoffrey Robertson, in his book "Crimes against Humanity, states that:

If US dose not fairly deal with human rights and defend its friend such as Israel and Saudi Arabia, or prescribe injustice for others, US benevolent leadership, cited by Samuel Huntington, would lead to the discriminatory and unfair practices and human rights. Unfortunately, there are no human rights in the United States. More importantly, there are also no human rights in prisons. The conditions are horrible in some prisons in the United States and female prisoners are frequently raped. In some states, prisoner's, both man and woman, hand and feet are chained in such a way that the wrists and ankles are closed to each other. Guards who line the prisoners are equipped with chemical sprayers and electric whip. In the United States, similar to other wealthy countries, the poor are not able adopt lawyers and death penalty are applied regardless of the Economic and Social Council of the United Nations standards. The common result of hiring incompetent lawyers is only wrong decisions especially in the case of those sentenced to death. The number of people executed annually in America is almost equal with the annual number of people who were executed on the orders of Pinochet. US appear to regularly destroy its citizens (Robertson, 2004: 558-560).

Freedom, justice, and human rights are highly instable and fragile in the United States, while cyber space illustrates a different picture. Soft power is only a tool to reflect the inside-outside and top-down attitude in order to smooth the domination on minds and access to exclusive benefits. Domination and injustice are natural elements of America's policies. Nye's soft power theory has failed to interpret America's political realities from inside to outside and from top to down. Imam Ali's soft-power management strategies is based on globalization in line with social justice and human rights from inside to outside. If Human rights, justice, fairness, sacrifice, equality, invitation, freedom, and humanity respect, and even hard power elements such as command, threat, coercion, inducement, defense, etc. reflect social justice and rights, pragmatism appears and intelligent power is strengthened by the help of social forces. Nye states that:

Military hard power still remains critical; however, using military power is unfair such as Abu Ghraib and Guantanamo. Therefore, the hard power declines the soft power required to conquer the Muslims` minds. As a result, more terrorists are made. A distinguished terrorism expert, for instance, concludes that Iraq war and US inability to regulate strategy worsened anti-American extremism. It's not that military source should be used or not, because military resources can be used to produce hard or soft power behavior. Fighting and threats, 
behaviors of hard power, protection and assistance are soft power behaviors. Soft power behaviors range from public diplomacy and assistance programs. They help enabling environment; however, measuring their effects is difficult in short run (Nye, 2011: 224-337).

What makes America's hard power outputs to be considered unfair and Imam Ali's governance to be considered fair is setting priorities in management strategies. Although the principles of soft power management are similar in Islam and West such democracy, freedom, human rights, justice, equality, humanitarian aid, etc. they differ when it comes to management stage and power behavior conversion. Power management in West sets and regulates the elements of soft power management in line with self-interested and monopoly objectives. The outputs of this power are social injustice and cruelty. It means that mental identity of management elements are fixed in theory and do not promote to empirically objective identity. The agenda of such management strategy lead to a paradox between pragmatism and sloganeering and the aggressiveness of hard power appears known as unfairness by Nye. A terrorist act led to following justice in the agenda of human rights supporters to provide democracy and freedom by aggressiveness to a few countries. They believed in winning Muslims` minds. Justice, human rights, democracy, and freedom were elements spread in cyber space in line with west's management strategies in soft power. Soft power's indicators of legitimacy and appeal was advertised; however, management was incapable in the stage of power identity change and took advantage of hard power in order complete the soft power in line with promoting intelligent power and against soft power management elements. Non-overlapping aspects of software and hardware power led to gap in power aspects and showed the paradox. Soft power indicators were declining and hatred waves increased not only among the terrorists who attributed to Islam with myopia but also in the global level.

By regulating intelligent power priorities in line with common universal values which are an integral part of national and global interests of Islam, Imam Ali established Islam globalization in development Projects of social justice. The reflection of Imam Ali's political performances are the most important and valid document to acquit the purely political Islam from assassination and terrorism. These documents are both in hearts and history.

\section{The Application of Imam Ali`s Belief Crisis Theory to Find the Roots of Terrorism Thoughts}

The emergence of the Kharijites occurred during arbitration. The Kharijites initially were members of the "Party of Ali". They later rejected his leadership after he agreed to arbitration with Muawiyah rather than combat to decide the succession to the Caliphate following the Battle of Siffin. Ali's forces met Muawiyah's at the Battle of Siffin. Initially, the battle went against Muawiyah but on the brink of defeat, Muawiyah directed his army to hoist Qurans on their lances. That initiated discord among some of those who were in Ali's army. Muawiyah wanted to put the dispute between the two sides to arbitration in accordance with the Qur'an. A group of Ali's army mutinied demanding for Ali to agree to Muawiyah's proposal. As a result, Ali reluctantly presented his own representative for arbitration. The mutineers, however, put forward Abu Musa Ashaari, against Ali's wishes. They gradually set some rules and regulations and concluded that they need to discover the roots of corruption in the world of Islam (Norouzian, 2007: 145-148).

Kharijites [which means those who leave] are also known as "Mareqin" because they left Imam Ali. "Mareqin" is an arrow that passes the sign referred to Kharijites because they abandoned religion (Qaderi, 2003: 60-61). This name, provided by Imam Ali, is a valid document to acquit political Islam from assassination and terrorism. Kharijites were not terrorists as long as they were Muslims. As soon as they began terrorist acts, they were considered those who left the Islam by Imam Ali. Therefore, not only terrorist thought is false among the Muslims, terrorists who believe they are Muslims are not actually related to Islam. However, the terrorist act needs to be sought in trans-regional factors. The dominant discourse on terrorism is in condemning terrorism, especially suicide missions in Islam in order to prevent the investigation of political realities. Professor Robert Paige of the University of Chicago and author of "End the massacre: the scientific strategy of suicide acts" studied the 426 suicide attacks from 1980 to 2003. Professor Paige concluded that no relationship is found between Islam and terrorist suicide acts. He also believes that military occupation of foreign forces is the main contributing factor of suicide acts (Moqtader Khan, 2008: 76). Terrorism is not justifiable. Therefore, all countries condemn terrorism. In reality, most countries use terrorism against each other and even some times they establish terrorist groups. What goes on in Iraq is an example. It means that the governments involved in these events take advantage of the condition because Machiavellianism is not gone. All countries, in fact, seek to increase their power. All countries claim democracy and human rights; however, they are the first ones to damage the human rights (Naqib Zadeh, 2006: 10).

Establishing social order has been one of the most important strategies of Imam Ali s government. The law is considered the basis of setting social relationships by Imam Ali. Imam Ali believes that it is God`s law. In the 
political system formed by Imam Ali, freedom is both required to be protected and developed. As freedom is considered a value, social order is also considered a value in Islamic community. Since all of these principles should complement each other to approach the rational life, it is natural to create some constraints for each other. Therefore, in order not to deregulate the social order, they raise some borders in which the most important ones are Law and Ethics (Mandegar, 2002: 245-249). That is why Imam Ali told Kharijites that: you [Kharijites] are the worst group of people (Nahj Al-Balagheh, Part127: 171). It means that terrorist groups such as Al-Jihad, Al Qaeda, the Taliban, the Islamic State, etc. are not only related to Islam but also are an opportunity for anti-Islam discourse in order to challenge the Islamic discourse in international level. The strongest approach which has been created to analyze the terrorism is a logical and rational strategy. Robert A. Pip is one of those who studied in this field. He believes that terrorism follows a strategic approach. Generally, Robert collected 188 suicide acts around the world from 1980 to 2001 in order to prove that the terrorism is a strategic approach. He explained that terrorist organizations rate such attacks efficient (Firahi and Zahiri, 2008: 161). In Imam Ali’s point of view, what causes the formation of terrorist associations in political Islam is the spread of false ideas under the guise of truth. These thoughts are supplied in false side. This is the main theme of Imam Ali 's Belief Crisis Theory concerning the analysis of terrorist thoughts. At the end of Nahrawan battle, Imam Ali said:

Do not fight with the Kharijites after me because those who followed rights are not similar to those who sought false. (Nahj Al-Balagheh, Part61: 79)

If Imam Ali asks not to fight with Kharijites, it means that the roots of terrorist groups need to be dried in order to prevent the growth. If he differentiates those who seek right and made a mistake with those who seeks false, it means no neglect of the agents promoting terrorist ideas because they are potential to grow and expand in the space of belief crisis. False thoughts are the most contributing factor for weak right side. He mentioned after the end of Seffin battle during arbitration:

Indeed, the emergence of seditions is heresies in Islamic rules. Innovations to which the Holy Quran opposes are against the God.

If false and right were not mixed, it was discovered. If the right were separated the false and became pure, enemies' tongues would be cut. If part of the right and part of the false were taken into account, Satan dominates friends. Those in favor of God would survive (Nahj Al-Balagheh, Part50: 71)

While investigating the roots of terrorism, Imam Ali`s Belief Crisis Theory leads to two separate group of players with different roles. The original player is behind the scene and the target player is in the scene. Original player, who is the mastermind and the main perpetrators of terrorist establishments, supply terrorist groups by creating ambiguity in the target player's beliefs. That Muhammad abd-al-Salam Faraj, the leader of Al-Jihad Terrorist Group in his book "Neglected Duty" believes that lack of participation in Jihad declines the Islam is a strong belief. He institutionalizes lack of participation in Jihad in minds of people. Then, he displays injustice and aggressiveness in Jihad of body organs. Here, the crisis of beliefs is formed. Imam Ali says that:

God, you know, we did not go to battle to win power and wealth but we wanted to restore the symbols of rights and religion and modify your lands (Nahj Al-Balagheh, Part131: 175).

Based upon Imam Ali`s words, the definitive goal of Islamic government is to balance the social justice. It supplies the national and global benefits of Islam in line with establishing global security and peace. Imam Ali follows the ideology of opposing the injustice and defending the oppressed. This ideology is possible in the management strategy of human equality to have equal rights. What is considered valuable in Islam regarding Jihad is its meaning. Defending the oppressed is always prescribed by following equal rights and justice. Jihad alone is not valuable. Values have mental identities. In reality, they are not able to reach the objective identity. The importance of the public in Islam concerning the human life's value can be evaluated by red lines and unlawful killings even when the Muslim armed forces are against enemy forces. Killing children, women, the elderly and the disabled, religious leaders and businessmen is strictly forbidden. Those who gave up their guns are prisoned at their homes, looking for shelters. They should not be killed. Places of worship, buildings, farms, and even trees must not be destroyed. The general public should not be invaded (Tahir-ul-qadri, 2010:9).

\section{Conclusion}

Among all theoretical crises in meaning and concept, Imam Ali raised the Crisis of Beliefs. The most acute ones are those which led the world to the World War such as ideologies in the crisis of German Nazism, Italian fascism crisis, or the crisis of Soviet communism. Individual beliefs in the Crisis of Beliefs destroy not only the human but also the life. This crisis is similar to double-edged sword: it can create challenge and opportunity at the same time. It is natural that some countries take advantage of this tool to dominate on rival discourse. Are we 
able to guarantee the environmental security and humanity when there are such terrorist groups in the era of information and nuclear weapons?

Some took the flag of Islam in the East and began to kill women, children, and innocent people only due to having different ideas. They say that "Today. Islam cannot go ahead with the objective". Jihad, regardless of its value, is relevant to domestic purposes to defend Islam. Others, in the west, took the flag of human rights starting genocide and killing women, children, and innocent people only because of difference in opinion.

They say "you are with us or against us". Then, the preventive war came along regardless of human rights. They even went further. They are believed not to be Muslims nor the supporter of human rights. What is clear is the equality in both terrorist groups but with different identities.

The study of terrorism roots in Imam Ali's thoughts shows that response to terrorism is not separable from its roots. Although some factors are effective in terrorism such as poverty, injustice, discrimination, inequality, etc. the Crisis of Beliefs is the main factor to show violent behaviors within terrorist groups. Poverty, injustice, discrimination, monopolization, etc. can be effective factors in terrorist behaviors as dependent variables; however, they cannot justify the roots of terrorist performance as independent variable. Terrorists, violent and aggressive killing of children, women, and innocent people are their objectives because they believe that their aims is higher than the life of victims. What they are involved in is the Crisis of Beliefs. That is why some play the role of terrorist thought promoters due to limitations, and national and international rules and regulations as the trees of terrorism. Others play the role of terrorist functions without the knowledge of the preset objectives.

\section{References}

Abdollahi, M. (2009). Terrorism: human rights and humanitarian law. Tehran: Legal Studies and Research Institute of Knowledge.

Alikhani, A. A. (2001). enemies and opponents in the political attitude of Imam Ali. Social Sciences: Methodology of Human Sciences, No. 26. Retrieved from http://www.noormags.irlviewlfalarticlepage 19409

Bernstein, T. M. (1965). The careful writer: A modern guide to English usage (2nd ed.). New York, NY: Atheneum.

Campos, N. F., \& Gassebner, M. (2009). International Terrorism, Political Instability and the Escalation Effect. Germany: Iza.

Chaliand, G., \& Blin, A. (2007). The History of Terrorism From Antiquity to Al Qaeda. Published with the assistance of the French ministry of cultures national center for the book.

Chung, A. (2012). Soft power in foreign policy with emphasis on the global information space. Translation: M. Zolfaghari. Tehran: University of Imam Sadeq.

Country Reports On Terrorism 2013. (2014). United States Department of State Publication.

Country Reports On Terrorism 2014. (2015). United States Department of State Publication.

Dardariyan, James and others. (2003). Terrorism, history, sociology, law, and discourse. Translation: Vahid Bozorgi and others. Tehran: Nei Press.

Dashti, M. (2006). Translation of Nahj al-Balagha. Qom, Imam Ali Research Institute

Firahy, D., \& Zahir, S. (1387). Terrorism, by definition, history and strategies in analyzing the phenomenon of terrorism. Political Science: Politics, Issue 3. Retrieved from http://www.noormags.irlview/falarticlepagel387945

Gerges, F. (2003). America and political Islam. Translation: Muhammad Kamal Sarvarian. Tehran: Center for Strategic Studies.

Holy Quran.

Ibne Abi Al-Hadid, E. (1996). The Effects of History in Nahj Al-balagheh (Viol. 1). Translation: Mahmoud Mahdavi Damqani. Tehran: Nei Press.

Ibne Abi Al-Hadid, E. (2008). Interpretation of Nahj Al-Balagheh (Vol. 2). Qom: School of Ayat Allah Mar`ashi Najafi Ameh.

Mandegar, M. M. (2002). Nahj Al-Balagheh policies. Qom: Qom garden book.

Moazzami, S., \& Nmamya, P. (2014). Rights in international documents to combat nuclear terrorism. Tehran: Dadgostar Press. 
Moqtderkhan, M. A. (2008). The increase in terrorist attacks seven years after the war against terrorism. Political Science: Exploring the West, No. 68. Retrieved from http://www.noormags.irlview/falarticlepagel359842.

Naghibzadeh, A. (2006). Manifest and latent functions terrorism. Interdisciplinary: time, number 51. Retrieved from http://www.noormags.irlview〉falarticlepagel382572

Noroozian, R. (2007). Political events during the reign of Imam Ali (AS). Qom: Iranian Revolutionary Guards Islamic Revolution, the Islamic Research Institute, publisher of Zamzam Hedayat.

Nye, J. S. (2010). Soft power tools for success in international politics. Translation: Mehdi Seyed Mohsen Rouhani and zolfaghari (Introduction: Asghar Eftekhari). Tehran: University of Imam Sadeq.

Nye, J. S. (2011). The Future of Power. Translation: Sahraee, R.; Shariat Panahi,S. T.; and Arjany, S. H.. Tehran: The Institute of Horoufieh with the help of new research and development institute of Novin scientist.

Parmer, I., \& Cox, M. (2012). Soft Power and America `s Foreign Policy: Theoretical, Historical, and New View Points. Translation: Javad Ali Pour. Tehran: Imam Sadeq University.

Pawlak, P. (2015). Global Terrorism: Trends in 2014/2015. European Parliament.

Plous, S., \& Zimbardo, P. G. (2004). How Social Science Can Reduce Terrorism. The chronicle of higher education.

Qaderi, H. (1382). Political Thought in Islam and Iran. Tehran: Organization of Study and Compilation of Humanities Books universities (Samt press).

Reich, W. (2002). The roots of terrorism. Translation: Seyyed Mohammad Najm. Tehran: Iranian Revolutionary Guards of the Islamic Revolution Command and General Staff College, the Supreme War period.

Robertson, J. (2004). Crimes against humanity. Translation: Translation Research Group Razavi University of Islamic Sciences, under the supervision of Hossein Sadeghi. Mashhad: Razavi University of Islamic Sciences.

Scheinin, M. (2008). Talking About Terrorism Risks and Choices For Human Rights Organizations. Switzerland: International council on Human rights policy.

Tahir-ul-Qadri, M. (2010). Fatwa on Terrorism and Suicide Bombings. Landon: Minhaj-ul-Quran international (UK).

\section{Copyrights}

Copyright for this article is retained by the author(s), with first publication rights granted to the journal.

This is an open-access article distributed under the terms and conditions of the Creative Commons Attribution license (http://creativecommons.org/licenses/by/4.0/). 